\title{
The Lower Peripheral Blood Lymphocyte to Monocyte Ratio Following Completion of First Line Chemotherapy Is a Risk Factor for Predicting Relapse in Patients with Diffuse Large B-Cell Lymphoma
}

\author{
Ghada Ezzat Eladawei1 ${ }^{*}$, Sheref Mohamed El-Taher ${ }^{2}$ \\ ${ }^{1}$ Clinical Oncology and Nuclear Medicine Department, Mansoura University, Mansoura, Egypt \\ ${ }^{2}$ Public Health \& Community Medicine Department, Benha University, Benha, Egypt \\ Email: ^ghadaeladawy@hotmail.com, sherefmoh@gmail.com
}

How to cite this paper: Eladawei, G.E. and El-Taher, S.M. (2019) The Lower Peripheral Blood Lymphocyte to Monocyte Ratio Following Completion of First Line Chemotherapy Is a Risk Factor for Predicting Relapse in Patients with Diffuse Large B-Cell Lymphoma. Journal of Cancer Therapy, 10, 53-68.

https://doi.org/10.4236/jct.2019.101005

Received: December 18, 2018

Accepted: January 20, 2019

Published: January 23, 2019

Copyright $\odot 2019$ by author(s) and Scientific Research Publishing Inc. This work is licensed under the Creative Commons Attribution International License (CC BY 4.0).

http://creativecommons.org/licenses/by/4.0/

\begin{abstract}
Background and objective: During routine follow up, there is no specific predictor to ascertain relapse after standard first line chemotherapy in diffuse large cell lymphoma. Therefore, this study was designed to assess the prognostic significance of the ratio between absolute lymphocyte and monocyte counts (LMR) in the peripheral blood to verify relapse in diffuse large B cell lymphoma. Patients and methods: A total of 139 patients with newly diagnosed diffuse large B cell lymphoma (DLBCL) were evaluated and treated with CHOP or R-CHOP between the years 2009 and 2016. Three months following completion of first line therapy, Lymphocyte/monocyte ratio (LMR) was calculated from the routine automated complete blood cell count (CBC) attained a plateau after the bone marrow recovery after first line chemotherapy. The absolute lymphocyte count/absolute monocyte count ratio (LMR) was calculated by dividing the ALC by the AMC. Results: ROC curve analysis of 139 patients established 2.8 as cutoff point of LMR for relapse with AUC of 0.97 (95\% CI $0.93-0.99, \mathrm{P} \leq 0.001)$. Cox regression analysis was performed to identify factors predicting relapse. In univariate regression analysis, ALC (95\% CI $0.003-0.03, \mathrm{p} \leq 0.001)$, AMC (95\% CI $15.4-128.8, \mathrm{p} \leq 0.001)$, LMR (95\% CI $0.001-0.01, \mathrm{p} \leq 0.001)$, and LDH (95\% CI $0.1-0.5, \mathrm{p} \leq 0.001)$ following completion of therapy are significant factors for relapse. Other significant factors for relapse are Ann Arbor stage (95\% CI 1.1 - 6.9, P = 0.03), extranodal sites (95\% CI $1.2-6.1, \mathrm{P}=0.01)$, age $(95 \% \mathrm{CI} 1.3-6.5, \mathrm{P}=0.01)$ and treatment of $\mathrm{CHOP}$ protocol $(95 \% \mathrm{CI} 0.05-0.6, \mathrm{P}=0.007)$. In a multivariate analysis LMR following completion of therapy was predictive for relapse
\end{abstract}


(95\% CI $0.001-0.2, \mathrm{P}=0.005)$. ALC was also significant in multivariate analysis (95\% CI $0.01-0.8, \mathrm{P}=0.03$ ). LDH following completion of therapy (95\% CI 0.2 - 14.9, $\mathrm{P}=0.5$ ), AMC following completion of therapy (95\% CI 0.3 43.1, $\mathrm{P}=0.3$ ), age (95\% CI 0.9 - 205.4, $\mathrm{P}=0.06$ ), extra-nodal sites (95\% CI $0.04-9.8, \mathrm{P}=0.8$ ), Ann Arbor stage (95\% CI 0.3 - 28.7, P = 0.3), and Treatment of CHOP protocol (95\% CI $0.01-2.4, \mathrm{P}=0.2)$ were not statistically significant. Conclusion: This study observed that LMR assessed after first line chemotherapy during routine follow up is an independent predictor of relapse and clinical outcome in DLBCL patients. LMR at follow up can be used a simple inexpensive biomarker to alert clinicians for relapse during follow up after standard first line chemotherapy in DLBCL patients.

\section{Keywords}

Diffuse Large B Cell Lymphoma, Absolute Lymphocyte Count/Absolute Monocyte Count Ratio, Relapse, Follow up

\section{Introduction}

Diffuse large B-cell lymphoma (DLBCL) is the most common subtype of lymphoid neoplasm as it represents $25 \%$ - $30 \%$ of all newly diagnosed cases of adult Non-Hodgkin lymphoma (NHL) [1]. Although it is an aggressive type of lymphoma, it is potentially curable.

The routine addition of rituximab therapy improved the overall survival of patients with DLBCL. However, approximately one-third of the patients develop relapsed/refractory disease that remains a major cause of morbidity and mortality [2].

Clinical outcome in DLBCL patients treated with standard therapy is assessed by risk factors before treatment implementation, such as the international prognostic index (IPI) [3], Immunohistochemistery-based detection [4] [5] or gene expression profiling [6] [7].

Immunodeficiency is one of the strongest risk factors of non-Hodgkin lymphoma [8]. Gene-expression profiling (GEP) studies showed a relationship between lymphoma biology and the host immune system, and suggested that gene signatures related to nonmalignant tumor microenvironment played an important role in the clinical outcomes of patients with NHL [9] [10] [11].

In spite of the fact that specific gene signatures of host immunity can predict prognosis of DLBCL patients, it is impractical for application on routine basis due to coast and technical limitation. Therefore, a large number of studies have therefore focused on the search for surrogate biomarkers which are immunologically relevant and can serve as prognostic factors [11] [12] [13].

During follow up after standard therapy in DLBCL, lactic dehydrogenase $(\mathrm{LDH})$ is an inexpensive factor that helps to identify patients who might require further evaluation for relapse. $\mathrm{LDH}$ has been reported to have a sensitivity of $42 \%$ and a specificity of $85 \%$ to predict relapse during follow-up [14]. 
Absolute lymphocyte count/absolute monocyte ratio (ALC/AMC ratio) is simple biomarker combining an estimate of host immune homeostasis and tumor microenvironment. Recently, ALC/AMC ratio at diagnosis was shown to be independent prognostic indicator in DLBCL [15] [16] [17].

During routine follow up, there is no specific predictor to ascertain risk for relapse after standard first line chemotherapy. Therefore, this study was designed to assess the prognostic significance of the ratio between absolute lymphocyte and monocyte counts (ALC/AMC ratio) in the peripheral blood to verify relapse in diffuse large $\mathrm{B}$ cell lymphoma.

\section{Patients \& Methods}

This is retrospective study was conducted in clinical oncology \& nuclear medicine, Mansoura University between the years 2009 and 2016. A total 139 patients with newly diagnosed diffuse large B cell lymphoma (DLBCL) who were evaluated and treated with CHOP (cyclophosphamide, hydroxydaunorubicin, vincristine, prednisone) or R-CHOP (rituximab-cyclophosphamide, hydroxydaunorubicin, vincristine, prednisone).

We excluded patients with primary DLBCL central nervous system lymphoma, transformed NHL, positive human immunodeficiency virus, who underwent upfront autologous stem cell transplantation during first line treatment or progressed during standard first line chemotherapy or lost follow up.

\subsection{Study Objective}

The primary aim of the study was to assess the ability of the LMR after completion of first-line therapy to predict relapse of DLBCL. We also evaluated whether the LMR affected overall survival (OS) and disease-free survival (DFS); we performed a landmark analysis commencing 3 months after completion of chemotherapy when the patients were in complete remission which was confirmed by CT scans.

Following completion of first line therapy, we calculated LMR from the routine automated complete blood cell count $(\mathrm{CBC})$ attained a plateau after the bone marrow recovery after first line chemotherapy. In our routine follow up CBC was done after 3 months after completion of chemotherapy. Therefore, we used the LMR data from the 3-month follow-up visits.

The absolute lymphocyte count/absolute monocyte count ratio (LMR) was calculated by dividing the ALC by the AMC.

Response and relapse criteria were based on the criteria from the International Harmonization Project [18]. Overall survival (OS) was measured from the day following completion of first-line therapy until the date of death from any cause, or date of the last follow-up. Disease free survival (DFS) measured from the day following completion of first-line therapy until the date of first lymphoma relapse, death from any cause, or date of the last follow-up.

Follow-up procedures usually included a physical examination, blood tests 
(LDH, CBC) and CT scans to monitor the disease status every 3 months in the first year, and every 6 months for 2 years then once a year in our hospitals.

Other prognostic factors tested in the study included lactate dehydrogenase $(\mathrm{LDH})$ at 3 months after completion of chemotherapy when the patients were in complete remission, IPI at the time of diagnosis [age $<60$ vs. $\geq 60$ years, Ann Arbor stage (III/IV vs. I/II), Eastern Cooperative Oncology Group performance status (ECOG PS) ( $\leq 1$ vs. $>1$ ), LDH (>normal vs. normal) and number of extra nodal sites (ENS) involved ( $\leq 1$ vs. $>1)$ ] were utilized.

\subsection{Statistical Analysis}

All statistical analyses were performed using SPSS statistical software (version 21). Receiver operating characteristic (ROC) curve analysis was used to determine the optimal LMR cutoffs yielding the maximal combined sensitivities and specificities.

Correlations of the ALC, AMC, and LMR with clinical parameters were evaluated using the chi-square or Fisher's exact test. OS and PFS were analyzed using Kaplan-Meier curves, which were compared using the log-rank test. Cox regression model was applied in both univariate and multivariate analyses to prognostic variables to predict relapse. Categorical variables were compared using the chi-square test. $\mathrm{P}$ value of $<0.05$ was considered statistically significant.

\section{Results}

\subsection{Patient Characteristics}

Retrospectively, we analyzed data of a total 139 DLBCL patients in this study. The median age was 48 years (range 21 - 67 years). There were 82 male and 57 female. $82 \%$ of patients had ECOG performance status $0-1.67 .6 \%$ of patients presented with III - IV stage. $25.2 \%$ of patients had $0-1$ IPI and $78.4 \%$ of patients had 2 - 3 IPI. $25.2 \%$ of patients received R-CHOP protocol. The median absolute lymphocyte count following completion of first line therapy was 1290/uL (interquartile range 770 - 1870). The median absolute monocyte counts 390/uL (interquartile range 200 - 680). Median LMR was 3.8 (range 1.3 - 6). The baseline characteristic for these patients is presented in Table 1.

Median follow up was 48 months (range 16 - 84 months). Among 139 patients, 39 patients $(28.1 \%)$ had relapsed disease. Early relapse defined as relapse occurred less than 12 month.

Fourteen patients $(10.07 \%)$ showed early relapsed disease with median LMR 1.7 (range $1.3-2.1$ ).

\subsection{Cut off Values for the ALC, AMC, and LMR as Marker for Relapse}

The choice of the best cutoff in predicting relapse was selected by receiver operating characteristic (ROC) curves and calculated areas under the curves (AUCs). The most discriminative cutoff value of ALC was 1170 cells/UL with AUC of 
0.94 [95\% CI $0.9-0.99, \mathrm{P} \leq 0.001$ ) (Figure 1(a)). AMC was 445 cells/UL with AUC of 0.91 [95\% CI $0.86-0.96, \mathrm{P} \leq 0.001$ ) (Figure 1(b)). ROC curve analysis of 139 patients established 2.8 as cutoff point of LMR for relapse with AUC of 0.97 [95\% CI $0.93-0.99, \mathrm{P} \leq 0.001$ ) (Figure $1(\mathrm{c})$ ).

Table 1. Patient characteristic.

\begin{tabular}{|c|c|c|}
\hline Characteristics & Number & $\%$ \\
\hline $\begin{array}{c}\text { Age (years) } \\
\text { Median (range) }\end{array}$ & $48(21-67)$ & \\
\hline \multicolumn{3}{|l|}{ Sex } \\
\hline Male & 82 & $59 \%$ \\
\hline Female & 57 & $41 \%$ \\
\hline \multicolumn{3}{|l|}{ ECOG PS } \\
\hline 0 & 40 & $28.8 \%$ \\
\hline 1 & 74 & $53.2 \%$ \\
\hline 2 & 25 & $18 \%$ \\
\hline \multicolumn{3}{|l|}{ Number of extra-nodal sites } \\
\hline 0 & 63 & $45.3 \%$ \\
\hline 1 & 57 & $41 \%$ \\
\hline 2 & 19 & $13.7 \%$ \\
\hline \multicolumn{3}{|l|}{ Stage } \\
\hline 1 & 4 & $2.9 \%$ \\
\hline 2 & 41 & $29.5 \%$ \\
\hline 3 & 63 & $45.3 \%$ \\
\hline 4 & 31 & $22.3 \%$ \\
\hline \multicolumn{3}{|l|}{ IPI } \\
\hline 0 & 15 & $10.8 \%$ \\
\hline 1 & 20 & $14.4 \%$ \\
\hline 2 & 40 & $28.8 \%$ \\
\hline 3 & 55 & $39.6 \%$ \\
\hline 4 & 8 & $5.8 \%$ \\
\hline 5 & 1 & $0.7 \%$ \\
\hline \multicolumn{3}{|l|}{ Treatment } \\
\hline $\mathrm{R}-\mathrm{CHOP}$ & 35 & $25.2 \%$ \\
\hline $\mathrm{CHOP}$ & 104 & $74.8 \%$ \\
\hline \multicolumn{3}{|l|}{ Following the completion of therapy } \\
\hline \multicolumn{3}{|l|}{ Median (Range). } \\
\hline Absolute lymphocyte count & $1290(770-1870)$ & \\
\hline Absolute monocyte count & $390(200-680)$ & \\
\hline Lymphocyte Monocyte ratio & $3.8(1.3-6)$ & \\
\hline \multicolumn{3}{|c|}{ LDH following completion of therapy } \\
\hline Normal & 91 & $65.5 \%$ \\
\hline$>$ Normal & 48 & $34.5 \%$ \\
\hline \multicolumn{3}{|l|}{ State of disease } \\
\hline Free (not relapsed) & 100 & $71.9 \%$ \\
\hline Relapsed & 39 & $28.1 \%$ \\
\hline
\end{tabular}

ECOG Eastern Cooperative Oncology Group, PS performance status, IPI International Prognostic Index, LDH lactate dehydrogenase. 


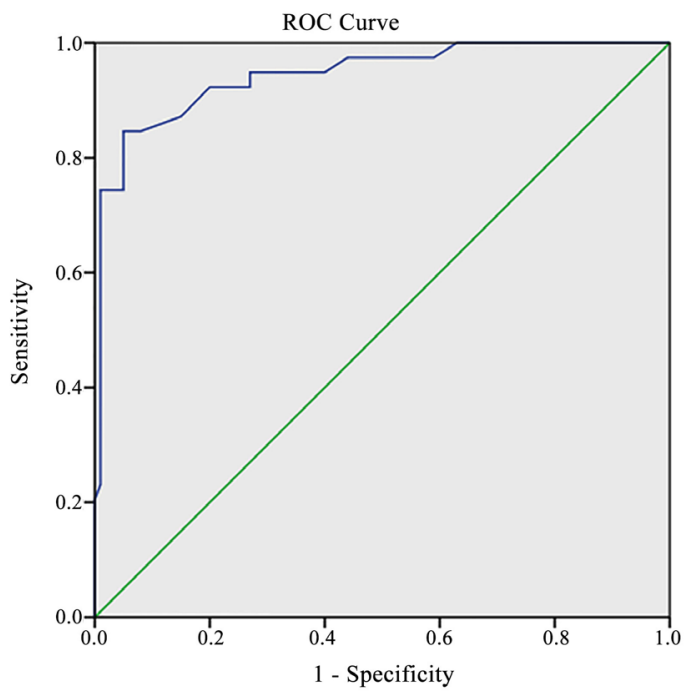

(a)

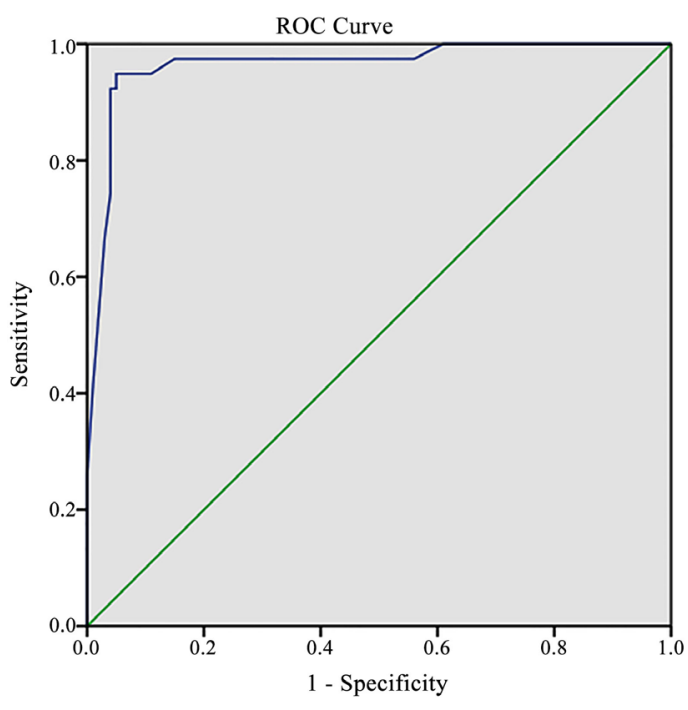

(b)

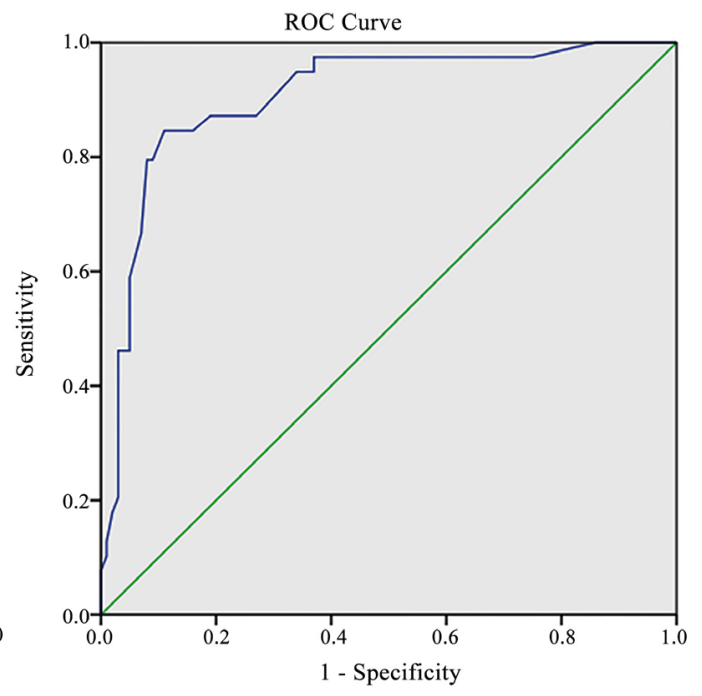

(c)

Figure 1. (a) Receiver operating characteristic (ROC) curve of absolute lymphocyte count as a marker for relapse. (b) Receiver operating characteristic (ROC) curve of absolute monocyte count as a marker for relapse. (c) Receiver operating characteristic (ROC) curve of lymphocyte monocyte ratio (LMR) as a marker for relapse.

\subsection{Comparison of Patients' Characteristic with LMR of $<2.8$ and $\geq 2.8$}

Clinical characteristic of the patients $(n=139)$ with $\operatorname{LMR} \geq 2.8$ and $<2.8$ are presented in Table 2. Forty two patients (30.2\%) had LMR $<2.85$ and ninety seven patients $(69.8 \%)$ had $L M R \geq 2.8$. A lower $L M R<2.8$ was significantly correlated with higher ECOG performance status $(\mathrm{p}=0.01)$, most of those patients received CHOP protocol ( $\mathrm{p}=0.005)$, lower ALC following completion of therapy ( $\mathrm{p} \leq 0.001)$, higher AMC following completion of therapy ( $\mathrm{p} \leq 0.001)$, more extra-nodal site $(\mathrm{p}=0.001)$, higher IPI score $(\mathrm{p} \leq 0.001)$ and higher LDH level ( $\mathrm{p}$ $\leq 0.001$ ) following completion of therapy. 
Table 2. Comparison of patient characteristics with lymphocyte monocyte ratio (LMR) of $\geq 2.85$ and $<2.85$.

\begin{tabular}{|c|c|c|c|}
\hline Characteristics & $\mathrm{LMR}<2.8(\mathrm{n}=42)$ & $\mathrm{LMR} \geq 2.8(\mathrm{n}=97)$ & $P$ value \\
\hline \multicolumn{4}{|l|}{ Age (years) } \\
\hline$<60$ & $28(66.7 \%)$ & $78(80.4 \%)$ & \multirow[t]{2}{*}{0.08} \\
\hline$\geq 60$ & $14(33.3 \%)$ & $19(19.6 \%)$ & \\
\hline \multicolumn{4}{|l|}{ Sex } \\
\hline Male & $26(61.9 \%)$ & $56(57.7 \%)$ & \multirow[t]{2}{*}{0.64} \\
\hline Female & $16(38.1 \%)$ & $41(42.3 \%)$ & \\
\hline \multicolumn{4}{|l|}{ ECOG PS } \\
\hline 0 & $6(14.3 \%)$ & $34(35 . \% 1)$ & \multirow{3}{*}{0.01} \\
\hline 1 & $24(57.1 \%)$ & $50(51.5 \%)$ & \\
\hline 2 & $12(28.6 \%)$ & $13(13.4 \%)$ & \\
\hline \multicolumn{4}{|l|}{ Extra-nodal sites } \\
\hline$>1$ & $10(23.8 \%)$ & $53(54.6 \%)$ & \multirow[t]{2}{*}{$0.001^{*}$} \\
\hline$\leq 1$ & $32(76.2 \%)$ & $44(45.4 \%)$ & \\
\hline \multicolumn{4}{|l|}{ Ann Arbor stage } \\
\hline I & $1(2.4 \%)$ & $3(3.1 \%)$ & \multirow{4}{*}{0.086} \\
\hline II & $7(16.7 \%)$ & $34(35.1 \%)$ & \\
\hline III & $23(54 \% .8)$ & $40(41.2 \%)$ & \\
\hline IV & $11(26.2 \%)$ & $20(20.6 \%)$ & \\
\hline \multicolumn{4}{|l|}{ IPI } \\
\hline 0 & $1(2.4 \%)$ & $14(14.4 \%)$ & \multirow{6}{*}{$<0.001^{\star}$} \\
\hline 1 & $1(2.4 \%)$ & $19(19.6 \%)$ & \\
\hline 2 & $11(26.2 \%)$ & $29(29.9 \%)$ & \\
\hline 3 & $21(50 \%)$ & $34(35.1 \%)$ & \\
\hline 4 & $7(16.7 \%)$ & $1(1 \%)$ & \\
\hline 5 & $1(2.4 \%)$ & $0(0.0 \%)$ & \\
\hline \multicolumn{4}{|l|}{ Treatment } \\
\hline $\mathrm{R}-\mathrm{CHOP}$ & $4(9.5 \%)$ & $31(32 \%)$ & \multirow[t]{2}{*}{0.005} \\
\hline $\mathrm{CHOP}$ & $38(90.5 \%)$ & $66(68 \%)$ & \\
\hline \multicolumn{4}{|c|}{$\begin{array}{c}\text { Following completion of } \\
\text { therapy }\end{array}$} \\
\hline ALC & $1025(770-1430)$ & $1320(1100-1870)$ & $<0.001^{*}$ \\
\hline AMC & $490(280-680)$ & $310(200-650)$ & $<0.001^{\star}$ \\
\hline \multicolumn{4}{|c|}{$\begin{array}{c}\text { Following completion of } \\
\text { therapy LDH }\end{array}$} \\
\hline Normal & $16(38.1 \%)$ & $75(77.3 \%)$ & \multirow{2}{*}{$<0.001^{*}$} \\
\hline$>$ Normal & $26(61.9 \%)$ & $22(22.7 \%)$ & \\
\hline \multicolumn{4}{|l|}{ State of disease } \\
\hline Follow up & $5(11.9 \%)$ & 95 (97.9\%) & \\
\hline Relapsed & $37(88.1 \%)$ & $2(2.1 \%)$ & $<0.001^{*}$ \\
\hline
\end{tabular}

ECOG Eastern Cooperative Oncology Group, PS performance status, IPI International Prognostic Index, LDH lactate dehydrogenase.

\subsection{Relapse Rate by Prognostic Factors}

Relapse rate was higher in patients with $\mathrm{LMR}<2.8, \mathrm{ALC}<1170, \mathrm{AMC} \geq 445$ and higher LDH after completion of chemotherapy $(94.9 \% \mathrm{P} \leq 0.001,84.6 \% \mathrm{P} \leq$ $0.001,79.5 \% \mathrm{p} \leq 0.001,59 \% \mathrm{p} \leq 0.001$ respectively). Also, the relapse rate was higher in patients with $(\geq 1)$ number of extra-nodal sites $(71.8 \% \mathrm{p}=0.01)$, stage III-IV ( $82 \% \mathrm{p}=0.02)$, CHOP protocol $(92.3 \% \mathrm{p}=0.003)$ and IPI $\geq 1$ score 
$(94.9 \% \mathrm{p}=0.001)$. However ECOG performance did not differ significantly between the two groups (Table 3 ).

\subsection{Prognostic Factors Predict Relapse}

Cox regression analysis was performed to identify factors predicting relapse. In univariate regression analysis, ALC (OR 0.01, 95\% CI $0.003-0.03, \mathrm{p} \leq 0.001$ ), AMC (OR 44.5, 95\% CI 15.4 - 128.8, p $\leq$ 0.001), LMR (OR 0.003, 95\% CI 0.001 $0.01, \mathrm{p} \leq 0.001$ ), and LDH (OR 0.23, 95\% CI $0.1-0.5, \mathrm{p} \leq 0.001$ ) following completion of therapy are significant factors for relapse. Other significant factors for relapse are Ann Arbor stage (OR 2.8, 95\% CI 1.1 - 6.9, p = 0.03), extranodal sites (OR 2.8, 95\% CI $1.2-6.1, \mathrm{p}=0.01$ ), age (OR 2.8, 95\% CI $1.3-6.5, \mathrm{p}=0.01$ ) and treatment of CHOP protocol (OR 0.18, 95\% CI $0.05-0.6, \mathrm{p}=0.007$ ) (Table 4).

Table 3. Prognostic factors for predicting relapse.

\begin{tabular}{|c|c|c|c|c|c|}
\hline & \multicolumn{4}{|c|}{ State of disease } & \multirow{3}{*}{$\mathbf{P}$} \\
\hline & \multicolumn{2}{|c|}{ No relapse } & \multicolumn{2}{|c|}{ relapsed } & \\
\hline & No & $\%$ & No & $\%$ & \\
\hline LMR & 5 & $5.0 \%$ & 37 & $94.9 \%$ & \\
\hline$<2.8$ & & & & & $<0.001$ \\
\hline$\geq 2.8$ & 95 & $95.0 \%$ & 2 & $5.1 \%$ & \\
\hline ALC & 5 & $5.0 \%$ & 33 & $84.6 \%$ & \\
\hline$<1170$ & & & & & $<0.001$ \\
\hline$\geq 1170$ & 95 & $95.0 \%$ & 6 & $15.4 \%$ & \\
\hline AMC & 92 & $92.0 \%$ & 8 & $20.5 \%$ & \\
\hline$<445$ & & & & & $<0.001$ \\
\hline$\geq 445$ & 8 & $8.0 \%$ & 31 & $79.5 \%$ & \\
\hline $\mathrm{LDH}$ & 75 & $75.0 \%$ & 16 & $41.0 \%$ & \\
\hline Normal & & & & & $<0.001^{*}$ \\
\hline$>$ normal & 25 & $25.0 \%$ & 23 & $59.0 \%$ & \\
\hline ECOG & 86 & $86 \%$ & 28 & $71.8 \%$ & \\
\hline$\leq 1$ & & & & & 0.08 \\
\hline 2 & 14 & $14 \%$ & 11 & $28.2 \%$ & \\
\hline Number of extra-sites & 52 & $52 \%$ & 11 & $28.2 \%$ & \\
\hline$<1$ & & & & & $0.01^{\star}$ \\
\hline$\geq 1$ & 48 & $48 \%$ & 28 & $71.8 \%$ & \\
\hline Stage & 38 & $38 \%$ & 7 & $18 \%$ & \\
\hline Stage I-II & & & & & $0.02^{\star}$ \\
\hline Stage III-IV & 62 & $62 \%$ & 32 & $82 \%$ & \\
\hline IPI2 & 33 & $33 \%$ & 2 & $5.1 \%$ & \\
\hline$\leq 1$ & & & & & $0.001^{*}$ \\
\hline$>1$ & 67 & $67 \%$ & 37 & $94.9 \%$ & \\
\hline Treatment & 32 & $32.0 \%$ & 3 & $7.7 \%$ & \\
\hline R-CHOP & & & & & 0.003 \\
\hline CHOP & 68 & $68.0 \%$ & 36 & $92.3 \%$ & \\
\hline
\end{tabular}


In a multivariate analysis LMR following completion of therapy was predictive for relapse (OR 0.01, 95\% CI $0.001-0.2, \mathrm{p}=0.005)$. ALC was also significant in multivariate analysis (OR $0.1,95 \%$ CI $0.01-0.8, \mathrm{p}=0.03$ ). LDH following completion of therapy (OR 1.9, 95\% CI $0.2-14.9, \mathrm{p}=0.5$ ), AMC following completion of therapy (OR 3.7, 95\% CI $0.3-43.1, \mathrm{p}=0.3$ ), age (OR 13.3, 95\% CI 0.9 205.4, $\mathrm{p}=0.06$ ), extra-nodal sites (OR 0.7, 95\% CI $0.04-9.8, \mathrm{p}=0.8$ ), Ann Arbor stage (OR 3.1, 95\% CI $0.3-28.7, \mathrm{p}=0.3$ ), and Treatment of CHOP protocol (OR $0.12,95 \%$ CI $0.01-2.4, \mathrm{p}=0.2$ ) were not statistically significant as shown in Table 4.

\subsection{Survival Analysis}

Disease free survival (DFS) and overall survival (OS) were analyzed according to LMR. After median follow up 48 months (range 16 - 84 months). There is significantly difference in DFS between LMR $\geq 2.8$ and LMR $<2.8\left(\mathrm{p} \leq 0.001^{\star}\right)$. Median DFS 15 month (range 6 - 37 month) in patients with LMR $<2.8$ in contrast to patients with LMR $\geq 2.8$ median DFS 37 month (range 13 - 86 month) Figure 2.

The median overall survival were also significantly longer for patients with LMR $\geq 2.8$ when compared with those patients LMR $<2.8$ (median OS 43 months versus 31 months respectively) $\mathrm{p} \leq 0.001^{\star}$ Figure 3 .

Table 4. Logistic regression univariate and multivariate analysis for relapse.

\begin{tabular}{|c|c|c|c|c|}
\hline \multirow{2}{*}{ Variable } & \multicolumn{2}{|c|}{$\begin{array}{l}\text { Univariate } \\
\text { analysis }\end{array}$} & \multicolumn{2}{|c|}{$\begin{array}{c}\text { Multivariate } \\
\text { analysis }\end{array}$} \\
\hline & OR (95\% CI) & P-value & OR $(95 \% \mathrm{CI})$ & $\mathrm{P}$ value \\
\hline Sex & $1.2(0.5-2.5)$ & 0.7 & $0.9(0.1-6.6)$ & 0.9 \\
\hline Age $\geq 60$ & $2.8(1.3-6.5)$ & 0.01 & $13.3(0.9-205.4)$ & 0.06 \\
\hline ECOG PS > 1 & $2.4(0.98-5.9)$ & 0.06 & $0.2(0.01-3.1)$ & 0.2 \\
\hline Extranodal sites $\geq 1$ & $2.8(1.2-6.1)$ & 0.01 & $0.7(0.04-9.8)$ & 0.8 \\
\hline $\begin{array}{l}\text { Ann arbor } \\
\text { stage III-IV }\end{array}$ & $2.8(1.1-6.9)$ & 0.03 & $3.1(0.3-28.7)$ & 0.3 \\
\hline Treatment CHOP & $0.18(0.05-0.6)$ & 0.007 & $0.12(0.01-2.4)$ & 0.2 \\
\hline $\begin{array}{l}\text { ALC }<1170 \\
\text { after compleletion of } \\
\text { therapy }\end{array}$ & $0.01(0.003-0.03)$ & $<0.001$ & $0.1(0.01-0.8)$ & 0.03 \\
\hline $\begin{array}{l}\mathrm{AMC} \geq 445 \\
\text { after compleletion of } \\
\text { therapy }\end{array}$ & $44.5(15.4-128.8)$ & $<0.001$ & $3.7(0.3-43.1)$ & 0.3 \\
\hline $\begin{array}{l}\mathrm{LMR}<2.85 \\
\text { after compleletion of } \\
\text { therapy }\end{array}$ & $0.003(0.001-0.01)$ & $<0.001$ & $0.01(0.001-0.2)$ & 0.005 \\
\hline $\begin{array}{l}\text { LDH }>\text { Normal } \\
\text { after compleletion of } \\
\text { therapy }\end{array}$ & $0.23(0.1-0.5)$ & $<0.001$ & $1.9(0.2-14.9)$ & 0.5 \\
\hline
\end{tabular}




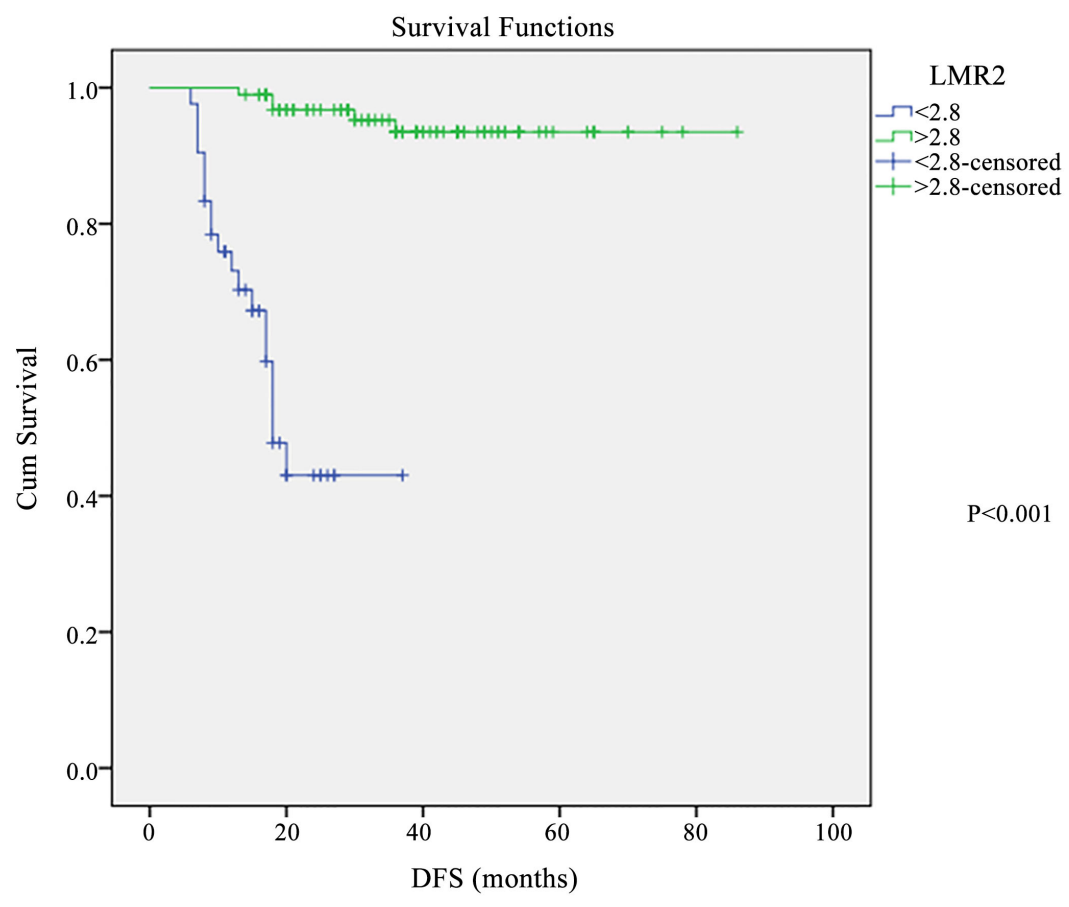

Figure 2. Disease free survival according Lymphocyte monocyte ratio (LMR).

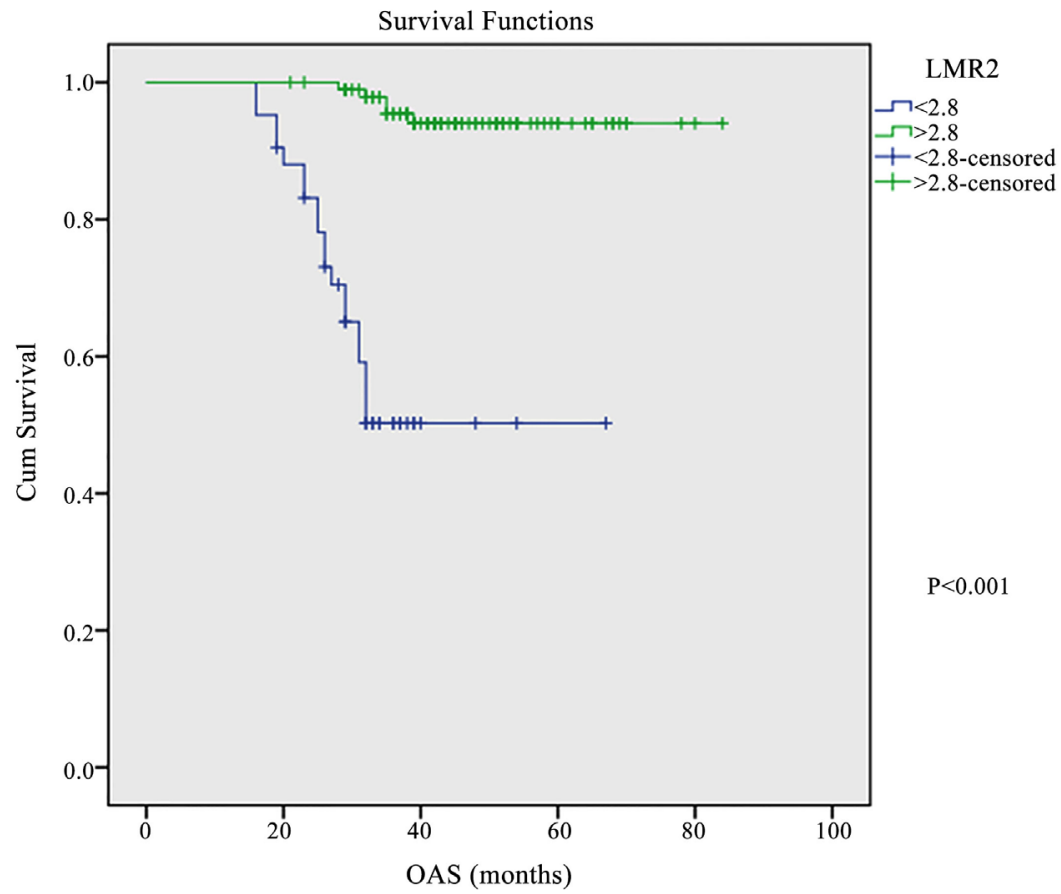

Figure 3. Overall survival according lymphocyte monocyte ratio (LMR).

\section{Discussion}

In spite of addition of anti-CD 20 monoclonal antibody rituximab in treatment of diffuse large B cell lymphoma, significant percentage of patients relapsed and that remain a major cause of mortality and morbidity [19].

The main objective of follow-up is to detect early relapse in order to improve 
outcome. Long term follow up according to the clinical indications or every 3 - 6 months in patients with DLBCL was currently recommended by the National Comprehensive Cancer Network [20]. Moreover, follow-up every 3 months for 1 year, every a half year for two years and afterward once per year in NHL patients was recommended by the European Society of Medical Oncology [21].

Careful history, physical examination and good clinical judgment are the most important items in monitoring patients after treatment [18]. More than $80 \%$ of relapse can be determined by patients or physicians, so regular surveillance CT scans is unsatisfactory for prediction of relapse [22] [23]. Furthermore, false positive results are frequent and unnecessary biopsies or additional scans will be done without need [24].

In asymptomatic DLBCL patients who achieved a complete response, routine assessment of lactic dehydrogenase is not recommended [25]. So, currently both ESMO and NCCN recommended follow up by blood counts and repeating CT scans only when clinically indicated [26].

Clinical outcome in DLBCL patients are assessed by risk factors identified before treatment [3] [4] [5] [6] [7]. During routine follow up, lymphopenia was found to be a risk factor for predicting relapse in DLBCL patients [6] [16].

Recently, gene expression profiling studies in NHL stated that gene expression by tumor-infiltrating lymphocytes and myeloid derived cells predict clinical outcome [17] [18].

In NHL patients, Lymphocytes have an important role in immune surveillance. Lymphopenia is considered a surrogate marker of host immunological incompetence [27] [28] [29] Furthermore, lymphocytes may be required for rituximab-mediated, antibody-dependent cell mediated cytotoxicity-dependent destruction of malignant B cells. Accordingly, lymphopenia is an adverse prognostic factor in indolent and aggressive NHL, including DLBCL [30].

Tumorigenesis and angiogenesis were promoted by myeloid-lineage cells, including monocytes and their progeny [29], These cells lead to the suppression of antitumor immunity and then, development of neutrophilia or monocytosis in the peripheral blood which are considered adverse prognostic factors in multiple solid tumors [30] [31] [32].

The LMR biomarker reflects the status of both immune homeostasis and the tumor microenvironment after treatment. LMR was shown to be an independent prognostic marker in patients with DLBCL patients [33].

In the current study, the choice of best cutoff values of ALC, AMC and LMR following completion of first line chemotherapy as markers for relapse were determined by constructed ROC curves and calculated area under curves. A low LMR (<2.8) following completion of first line chemotherapy was significantly correlated with relapse in univariate and multivariate analysis. The increased risk of relapse could be the result of either, failure of immune surveillance leading to clinical relapse or primary relapse produce mediators of immune suppression expressed as a decrease in ALC and a elevate in AMC. 
Li et al. 2014 retrospectively analyzed blood lymphocyte/monocyte ratio during routine follow up after standard first line chemotherapy (CHOP or R-CHOP). Patients with an ALC/AMC ratio $(<2.8)$ had a higher cumulative hazard rate of relapse compared with those had ALC/AMC ratio $\geq 2.8(\mathrm{p} \leq 0.001)$ [34]. Also, Zhou et al. 2017 stated that Low lymphocyte/monocyte ratio $<2.9$ was significantly correlated with early relapse in both univariate and multivariate analysis [26]. Our result was in accordance with those previous studies. On the other hand, YAMAUCHI et al. 2015 reported that low lymphocytes monocytes ratio was not predictive for disease relapse of advanced DLBCL [35].

In the present study, we observed that patients with high LMR $\geq 2.8$ after first line chemotherapy achieved significantly better PFS and longer survival than those with LMR. Many studies observed that low LMR is prognostic marker for survival of diffuse large B cell lymphoma patients [15] [16] [36] [37] [38]. Furthermore, an updated meta-analysis including twelve studies was performed to assess the relation between low LMR and survival of patients with diffuse large B-cell lymphoma. The meta-analysis stated that low LMR has adverse effect and poor survival of patients with diffuse large B cell lymphoma [33].

\section{Conclusion}

The current study is retrospective with relatively low number of patients to allow confirmation of diagnosis. So to minimize these biases we selected only patients with de novo DLBCL treated with standard first line chemotherapy. In addition, receiver operating characteristic curves and area under the curve were used to determine the best ALC, AMC, LMR cutoff value. This study observed that LMR assessed after first line chemotherapy during routine follow up is an independent predictor of relapse and clinical outcome in DLBCL patients. LMR at follow up can be used a simple inexpensive biomarker to alert clinicians of relapse during follow up after standard first line chemotherapy in DLBCL patients.

\section{Conflicts of Interest}

The authors declare no conflicts of interest regarding the publication of this paper.

\section{References}

[1] Habermann, T.M. (2012) New Developments in the Management of Diffuse Large B-Cell Lymphoma. Hematology, 17, S93-S97. https://doi.org/10.1179/102453312X13336169156014

[2] Pfreundschuh, M., Kuhnt, E., Trümper, L., Osterborg, A., Trneny, M., Shepherd, L., Gill, D.S., Walewski, J., Pettengell, R., Jaeger, U., Zinzani, P.L., Shpilberg, O., Kvaloy, S., de Nully Brown, P., Stahel, R., Milpied, N., López-Guillermo, A., Poeschel, V., Grass, S., Loeffler, M., Murawski, N. and MabThera International Trial (MInT) Group (2011) CHOP-Like Chemotherapy with or without Rituximab in Young Patients with Good-Prognosis Diffuse Large-B-Cell Lymphoma: 6-Year Results of an Open-Label Randomised Study of the MabThera International Trial (MInT) Group. Lancet Oncology, 12, 1013-1022. https://doi.org/10.1016/S1470-2045(11)70235-2 
[3] (1993) A Predictive Model for Aggressive Non-Hodgkin's Lymphoma. The International Non-Hodgkin's Lymphoma Prognostic Factors Project. New England Journal of Medicine, 329, 987-994. https://doi.org/10.1056/NEJM199309303291402

[4] Hans, C.P., Weisenburger, D.D., Greiner, T.C., Gascoyne, R.D., Delabie, J., Ott, G., Müller-Hermelink, H.K., Campo, E., Braziel, R.M., Jaffe, E.S., Pan, Z., Farinha, P., Smith, L.M., Falini, B., Banham, A.H., Rosenwald, A., Staudt, L.M., Connors, J.M., Armitage, J.O. and Chan, W.C. (2004) Confirmation of the Molecular Classification of Diffuse Large B-Cell Lymphoma by Immunohistochemistry Using a Tissue Microarray. Blood, 103, 275-282. https://doi.org/10.1182/blood-2003-05-1545

[5] Choi, W.W., Weisenburger, D.D., Greiner, T.C., Piris, M.A., Banham, A.H., Delabie, J., Braziel, R.M., Geng, H., Iqbal, J., Lenz, G., Vose, J.M., Hans, C.P., Fu, K., Smith, L.M., Li, M., Liu, Z., Gascoyne, R.D., Rosenwald, A., Ott, G., Rimsza, L.M., Campo, E., Jaffe, E.S., Jaye, D.L., Staudt, L.M. and Chan, W.C. (2009) A New Immunostain Algorithm Classifies Diffuse Large B-Cell Lymphoma into Molecular Subtypes with High Accuracy. Clinical Cancer Research, 15, 5494-5502.

https://doi.org/10.1158/1078-0432.CCR-09-0113

[6] Lenz, G., Wright, G.W., Emre, N.C., Kohlhammer, H., Dave, S.S., Davis, R.E., Carty, S., Lam, L.T., Shaffer, A.L., Xiao, W., Powell, J., Rosenwald, A., Ott, G., Muller-Hermelink, H.K., Gascoyne, R.D., Connors, J.M., Campo, E., Jaffe, E.S., Delabie, J., Smeland, E.B., Rimsza, L.M., Fisher, R.I., Weisenburger, D.D., Chan, W.C. and Staudt, L.M. (2008) Molecular Subtypes of Diffuse Large B-Cell Lymphoma Arise by Distinct Genetic Pathways. Proceedings of the National Academy of Sciences of USA, 105, 13520-13525. https://doi.org/10.1073/pnas.0804295105

[7] Scott, D.W., Wright, G.W., Williams, P.M., Lih, C.J., Walsh, W., Jaffe, E.S., Rosenwald, A., Campo, E., Chan, W.C., Connors, J.M., Smeland, E.B., Mottok, A., Braziel, R.M., Ott, G., Delabie, J., Tubbs, R.R., Cook, J.R., Weisenburger, D.D., Greiner, T.C., Glinsmann-Gibson, B.J., Fu, K., Staudt, L.M., Gascoyne, R.D. and Rimsza, L.M. (2014) Determining Cell-of-Origin Subtypes of Diffuse Large B-Cell Lymphoma Using Gene Expression in Formalin-Fixed Paraffin Embedded Tissue. Blood, 123, 1214-1217. https://doi.org/10.1182/blood-2013-11-536433

[8] Morton, L.M., Wang, S.S., Cozen, W., Linet, M.S., Chatterjee, N., Davis, S., Severson, R., Colt, J.S., Vasef, M.A., Rothman, N., Blair, A., Bernstein, L., Cross, A.J., De Roos, A.J., Engels, E.A., Hein, D.W., Hill, D.A., Kelemen, L.E., Lim, U., Lynch, C.F., Schenk, M., Wacholder, S., Ward, M.H., Zahm, S.H., Chanock, S.J., Cerhan, J.R. and Hartge, P. (2008) Etiologic Heterogeneity among Non-Hodgkin Lymphoma Subtypes. Blood, 112, 5150-5160. https://doi.org/10.1182/blood-2008-01-133587

[9] Dave, S.S., Wright, G., Tan, B., Rosenwald, A., Gascoyne, R.D., Chan, W.C., Fisher, R.I., Braziel, R.M., Rimsza, L.M., Grogan, T.M., Miller, T.P., LeBlanc, M., Greiner, T.C., Weisenburger, D.D., Lynch, J.C., Vose, J., Armitage, J.O., Smeland, E.B., Kvaloy, S., Holte, H., Delabie, J., Connors, J.M., Lansdorp, P.M., Ouyang, Q., Lister, T.A., Davies, A.J., Norton, A.J., Muller-Hermelink, H.K., Ott, G., Campo, E., Montserrat, E., Wilson, W.H., Jaffe, E.S., Simon, R., Yang, L., Powell, J., Zhao, H., Goldschmidt, N., Chiorazzi, M. and Staudt, L.M.(2004) Prediction of Survival in Follicular Lymphoma Based on Molecular Features of Tumor Infiltrating Immune Cells. New England Journal of Medicine, 351, 2159-2169. https://doi.org/10.1056/NEJMoa041869

[10] Lenz, G., Wright, G., Dave, S.S., Xiao, W., Powell, J., Zhao, H., Xu, W., Tan, B., Goldschmidt, N., Iqbal, J., Vose, J., Bast, M., Fu, K., Weisenburger, D.D., Greiner, T.C., Armitage, J.O., Kyle, A., May, L., Gascoyne, R.D., Connors, J.M., Troen, G., Holte, H., Kvaloy, S., Dierickx, D., Verhoef, G., Delabie, J., Smeland, E.B., Jares, P., 
Martinez, A., Lopez-Guillermo, A., Montserrat, E., Campo, E., Braziel, R.M., Miller, T.P., Rimsza, L.M., Cook, J.R., Pohlman, B., Sweetenham, J., Tubbs, R.R., Fisher, R.I., Hartmann, E., Rosenwald, A., Ott, G., Muller-Hermelink, H.K., Wrench, D., Lister, T.A., Jaffe, E.S., Wilson, W.H., Chan, W.C., Staudt, L.M. and Lymphoma/Leukemia Molecular Profiling Project (2008) Stromal Gene Signatures in Large-B-Cell Lymphomas. New England Journal of Medicine, 359, 2313-2323. https://doi.org/10.1056/NEJMoa0802885

[11] Steidl, C., Lee, T., Shah, S.P., Farinha, P., Han, G., Nayar, T., Delaney, A., Jones, S.J., Iqba, J., Weisenburger, D.D., Bast, M.A., Rosenwald, A., Muller-Hermelink, H.K., Rimsza, L.M., Campo, E., Delabie, J., Braziel, R.M., Cook, J.R., Tubbs, R.R., Jaffe, E.S., Lenz, G., Connors, J.M., Staudt, L.M., Chan, W.C. and Gascoyne, R.D. (2010) Tumor-Associated Macrophages and Survival in Classic Hodgkin's Lymphoma. The New England Journal of Medicine, 362, 875-885. https://doi.org/10.1056/NEJMoa0905680

[12] Wada, N., Zaki, M.A., Hori, Y., Hashimoto, K., Tsukaguchi, M., Tatsumi, Y., Ishikawa, J., Tominaga, N., Sakoda, H., Take, H., Tsudo, M., Kuwayama, M., Morii, E., Aozasa, K. and Osaka Lymphoma Study Group (2012) Tumour Associated Macrophages in Diffuse Large B-Cell Lymphoma: A Study of the Osaka Lymphoma Study Group. Histopathology, 60, 313-319. https://doi.org/10.1111/j.1365-2559.2011.04096.x

[13] Wada, N., Zaki, M.A., Kohara, M., Ogawa, H., Sugiyama, H., Nomura, S., Matsumura, I., Hino, M., Kanakura, Y., Inagaki, H., Morii, E. and Aozasa, K. (2012) Diffuse Large B Cell Lymphoma with an Interfollicular Pattern of Proliferation Shows a Favourable Prognosis: A Study of the Osaka Lymphoma Study Group. Histopathology, 60, 924-932. https://doi.org/10.1111/j.1365-2559.2011.04161.x

[14] Weeks, J.C., Yeap, B.Y., Canellos, G.P. and Shipp, M.A. (1991) Value of Follow-Up Procedures in Patients with Large-Cell Lymphoma Who Achieves a Complete Remission. Journal of Clinical Oncology, 9, 1196-1203.

https://doi.org/10.1200/JCO.1991.9.7.1196

[15] Li, Z.M., Huang, J.J., Xia, Y., Sun, J., Huang, Y., Wang, Y., Zhu, Y.J., Li, Y.J., Zhao, W., Wei, W.X., Lin, T.Y., Huang, H.Q. and Jiang, W.Q. (2012) Blood Lymphocyte-to-Monocyte Ratio Identifies High-Risk Patients in Diffuse Large B-Cell Lymphoma Treated with R-CHOP. PLOS ONE, 7, e 41658.

[16] Rambaldi, A., Boschini, C., Gritti, G., Delaini, F., Oldani, E., Rossi, A., Barbui, A.M., Caracciolo, D., Ladetto, M., Gueli, A., De Crescenzo, A., Passera, R., Devizzi, L., Patti, C., Gianni, A.M. and Tarella, C. (2013) The Lymphocyte to Monocyte Ratio Improves the IPI-Risk Definition of Diffuse Large B-Cell Lymphoma When Rituximab Is Added to Chemotherapy. American Journal of Hematology, 88, 1062-1067. https://doi.org/10.1002/ajh.23566

[17] Li, Y.L., Pan, Y.Y., Jiao, Y., Ning, J., Fan, Y.G. and Zhai, Z.M. (2014) Peripheral Blood Lymphocyte/Monocyte Ratio Predicts Outcome for Patients with Diffuse Large B Cell Lymphoma after Standard First-Line Regimens. Annals of Hematology, 93, 617-626. https://doi.org/10.1007/s00277-013-1916-9

[18] Cheson, B.D., Pfistner, B., Juweid, M.E., Gascoyne, R.D., Specht, L., Horning, S.J., Coiffier, B., Fisher, R.I., Hagenbeek, A., Zucca, E., Rosen, S.T., Stroobants, S., Lister, T.A., Hoppe, R.T., Dreyling, M., Tobinai, K., Vose, J.M., Connors, J.M., Federico, M., Diehl, V. and International Harmonization Project on Lymphoma (2007) Revised Response Criteria for Malignant Lymphoma. Journal of Clinical Oncology, 25, 579-586. https://doi.org/10.1200/JCO.2006.09.2403

[19] Friedberg, J.W. (2011) Relapsed/Refractory Diffuse Large B-Cell Lymphoma. He- 
matology, the ASH Education Program, 2011, 498-505. https://doi.org/10.1182/asheducation-2011.1.498

[20] National Comprehensive Cancer Network (NCCN) Diffuse Large B-Cell Lymphoma. Practice Guidelines in Oncology-v1.2012.

[21] Tilly, H., Gomes da Silva, M., Vitolo, U., Jack, A., Meignan, M., Lopez-Guillermo, A., Walewski, J., Andre, M., Johnson, P.W., Pfreundschuh, M. and Ladetto, M. (2015) Diffuse Large B-Cell Lymphoma (DLBCL): ESMO Clinical Practice Guidelines for Diagnosis, Treatment and Follow-Up. Annals of Oncology, 26, 116-125. https://doi.org/10.1093/annonc/mdv304

[22] Foltz, L.M., Song, K.W. and Connors, J.M. (2004) Who Actually Detects Relapse in Hodgkin Lymphoma: Patient or Physician. Blood, 104, 853-854.

[23] Liedtke, M., Hamlin, P.A., Moskowitz, C.H. and Zelenetz, A.D. (2006) Surveillance Imaging during Remission Identifies a Group of Patients with More Favorable Aggressive NHL at Time of Relapse: A Retrospective Analysis of a Uniformly-Treated Patient Population. Annals of Oncology, 17, 909-913.

https://doi.org/10.1093/annonc/mdl049

[24] Hong, J., Kim, J.H., Lee, K.H., Ahn, H.K., Park, S., Sym, S.J., Park, J., Cho, E.K., Shin, D.B. and Lee, J.H. (2014) Symptom-Oriented Clinical Detection versus Routine Imaging as a Monitoring Policy of Relapse in Patients with Diffuse Large B-Cell Lymphoma. Leukemia \& Lymphoma, 55, 2312-2318. https://doi.org/10.3109/10428194.2014.882505

[25] El-Sharkawi, D., Basu, S., Ocampo, C., Qian, W., D’Sa, S., Hoskin, P.J. and Ardeshna, K.M. (2012) Elevated Lactate Dehydrogenase Levels Detected during Routine Follow-Up Do Not Predict Relapse in Patients with Diffuse Large B-Cell Lymphoma Who Achieve Complete Remission after Primary Treatment with Rituximab, Cyclophosphamide, Doxorubicin, Vincristine and Prednisone-Like Immunochemotherapy. Leukemia \& Lymphoma, 53, 1949-1952. https://doi.org/10.3109/10428194.2012.679360

[26] Zhou, S.J., Ma, Y.Y., Zhang, Y., Luo, S., Tang, L.Y., Chen, Y., Sun, L. and Yu, K. (2017) Peripheral Blood Lymphocyte/Monocyte Ratio Following Completion of First-Line Therapy Predicts Early Relapse in Patients with Diffuse Large B Cell Lymphoma. Annals of Hematology, 96, 237-243. https://doi.org/10.1007/s00277-016-2865-x

[27] Oki, Y., Yamamoto, K., Kato, H., Kuwatsuka, Y., Taji, H., Kagami, Y. and Morishima, Y. (2008) Low Absolute Lymphocyte Count Is a Poor Prognostic Marker in Patients with Diffuse Large B-Cell Lymphoma and Suggests Patients' Survival Benefit from Rituximab. European Journal of Haematology, 81, 448-453.

https://doi.org/10.1111/j.1600-0609.2008.01129.x

[28] Kim, D.H., Baek, J.H., Chae, Y.S., Kim, Y.K., Kim, H.J., Park, Y.H., Song, H.S., Chung, J.S., Hyun, M.S. and Sohn, S.K. (2007) Absolute Lymphocyte Counts Predicts Response to Chemotherapy and Survival in Diffuse Large B-Cell Lymphoma. Leukemia, 21, 2227-2230. https://doi.org/10.1038/sj.leu.2404780

[29] Cox, M.C., Nofroni, I., Ruco, L., Amodeo, R., Ferrari, A., La Verde, G., Cardelli, P., Montefusco, E., Conte, E., Monarca, B. and Aloe-Spiriti, M.A. (2008) Low Absolute Lymphocyte Count Is a Poor Prognostic Factor in Diffuse Large B-Cell Lymphoma. Leukemia \& Lymphoma, 49, 1745-1751. https://doi.org/10.1080/10428190802226425

[30] Weiner, G.J. (2010) Rituximab: Mechanism of Action. Seminars in Hematology, 47, 115-123. https://doi.org/10.1053/j.seminhematol.2010.01.011 
[31] Gabrilovich, D.I. and Nagaraj, S. (2009) Myeloid-Derived Suppressor Cells as Regulators of the Immune System. Nature Reviews Immunology, 9, 162-174. https://doi.org/10.1038/nri2506

[32] Wilcox, R.A., Ristow, K., Habermann, T.M., Inwards, D.J., Micallef, I.N., Johnston, P.B., Colgan, J.P., Nowakowski, G.S., Ansell, S.M., Witzig, T.E., Markovic, S.N. and Porrata, L.(2011) The Absolute Monocyte and Lymphocyte Prognostic Score Predicts Survival and Identifies High-Risk Patients in Diffuse Large-B-Cell Lymphoma. Leukemia, 25, 1502-1509. https://doi.org/10.1038/leu.2011.112

[33] Kai, X.W., Feng, L.Q., Shen, D., Li, L.Z., Su, J. and Dong, M.W. (2016) Prognostic Significance of Lymphocyte-to-Monocyte Ratio in Diffuse Large B-Cell Lymphoma: A Systematic Review and Meta-Analysis. FEBS Open Bio, 6, 558-565. https://doi.org/10.1002/2211-5463.12066

[34] Li, L.Y., Gu, K.S., Pan, Y.Y., Jiao, Y. and Zhai, Z.M. (2014) The Lower Peripheral Blood Lymphocyte/Monocyte Ratio Assessed during Routine Follow-Up after Standard First-Line Chemotherapy Is a Risk Factor for Predicting Relapse in $\mathrm{Pa}$ tients with Diffuse Large B-Cell Lymphoma. Leukemia Research, 38, 323-328. https://doi.org/10.1016/j.leukres.2013.12.005

[35] Yamauchi, T., Tasaki, T., Tai, K., Ikegaya, S., Takagi, K., Negoro, E., Kishi, S., Yoshida, A., Iwasaki, H. and Ueda, T. (2015) Prognostic Effect of Peripheral Blood Cell Counts in Advanced Diffuse Large B-Cell Lymphoma Treated with R-CHOP-Like Chemotherapy: A Single Institution Analysis. Oncology Letters, 9, 851-856. https://doi.org/10.3892/ol.2014.2716

[36] Koh, Y.W., Park, C.S., Yoon, D.H., Suh, C. and Huh, J. (2014) Should the Cut-Off Values of the Lymphocyte to Monocyte Ratio for Prediction of Prognosis in Diffuse Large B-Cell Lymphoma Be Changed in Elderly Patients? European Journal of Haematology, 93, 340-348. https://doi.org/10.1111/ejh.12354

[37] Porrata, L.F., Inwards, D.J., Ansell, S.M., Micallef, I.N., Johnston, P.B., Hogan, W.J. and Markovic, S.N. (2014) Infused Autograft Lymphocyte to Monocyte Ratio and Survival in Diffuse Large B Cell Lymphoma. Biology of Blood and Marrow Transplantation, 20, 1804-1812. https://doi.org/10.1016/j.bbmt.2014.07.012

[38] Watanabe, R., Tomita, N., Itabashi, M., Ishibashi, D., Yamamoto, E., Koyama, S., Miyashita, K., Takahashi, H., Nakajima, Y., Hattori, Y., Motohashi, K., Takasaki, H., Ohshima, R., Hashimoto, C., Yamazaki, E., Fujimaki, K., Sakai, R., Fujisawa, S., Motomura, S. and Ishigatsubo, Y. (2014) Peripheral Blood Absolute Lymphocyte/Monocyte Ratio as a Useful Prognostic Factor in Diffuse Large B-Cell Lymphoma in the Rituximab Era. European Journal of Haematology, 92, 204-210. https://doi.org/10.1111/ejh.12221 